\title{
Life After a Sports Career: the Case of Polish Ex-fencers
}

Authors' contribution:

A) conception and design of the study

B) acquisition of data

C) analysis and interpretation of data

D) manuscript preparation

E) obtaining funding

\section{Agata Kucharska $^{1 \text { A-E }}$, Stanisław Witold Kłopot ${ }^{2}$ A-C}

\author{
${ }^{1}$ University School of Physical Education in Wroclaw, Poland \\ ${ }^{2}$ University of Wroclaw, Poland
}

\section{ABSTRACT}

The present study focuses on the issue of the achievement of stability in life by former amateur fencers in the context of post-communist Polish society. The main aim of the study was an analysis of non-sport spheres of life of former fencers, such as occupation, material situation, family life, and health. The sample consisted of 51 former Polish fencers. A diagnostic survey was conducted with the use of the questionnaire technique. It was revealed that the subjects successfully achieved social stability after they retired from sports. However, since they had been amateur athletes, they had been forced to choose appropriate strategies and actions during their sports careers to ensure professional, economic, and family stability in their future lives. Those who experienced difficulties in combining the role of athlete with other social roles were most often forced to give up fencing. The former fencers observe a multidirectional impact of sports on all aspects of their lives.

\section{KEYWORDS} ex-athletes, sports retirement, sports career, post-communism, fencers

\section{Introduction}

Every sports career must come to an end at some point, and every athlete must be aware that the greater part of his or her biography is a post-sports life. It is important, then, to study the problem of exathletes' lives in social reality after they retire from sports. Each model of sports career includes such stages as initiation/sampling, development/specialization, perfection/mastery/investment, final/maintenance, and discontinuation of competitive sports involvement (Stambulova, Alfermann, Stauer \& Côté, 2009 after: Bloom, 1985; Côté, 1999; Solmela, 1994; Stambulova, 1994; Wylleman \& Lavallee, 2004). The last stage is associated with experiencing significant changes in athletes' lives in the social, psychosocial, health, and economic spheres (Kadlcik \& Flemr, 2008). This transition can follow two types of juxtaposition: "crisistransition versus positive transition" (Kadlcik \& Flemr after Stambulova 1997, 2003) and "career transition distress versus healthy career transition" (Kadlcik \& Flemr after Taylor \& Ogilvie, 1994, 2001). Moreover, retirement from sports has been conceptualized by some researchers as aging (Lerch, 1984; McPherson, 1984; Rosenberg, 1981) or even as social death (Lerch, 1984; Rosenberg, 1984), whereas others have viewed it as social rebirth (Coakley, 1983). The latter view was also expressed by Kadlcik and Flemr, who claim that the end of a sports career does not have to be a negative event in an athlete's life (Kadlcik \& Flemr, 2008). In a review of literature on adjustment problems experienced by ex-athletes, Coakley examined the situation of former interscholastic, amateur, and professional athletes (1983). He concluded that, in many cases, the end of a sports career may offer new opportunities for potential development. 
Retirement from sports does not have to be associated with stress, identity crisis or adjustment problems, but it always takes place in a specific social context. Factors such as gender, race, age, socio-economic status, and social and emotional support can significantly affect its course. Former male athletes and middle class athletes can be more successful on the job market than female athletes or those from poorer families. In the social reality, being an athlete may not have significant advantages (Coakley, 1983).

Researchers have also noticed that, in addition to such psychological determinants as retirement planning, voluntary termination, identity change and active coping, cultural context is also crucial in the process of post-sports adaptation of former athletes. Unfortunately, very few studies have taken this factor into account (Stambulova, Alfermann, Stauer \& Côté, 2009). It turns out that, for example, athletes from Western Europe tend to plan the ending of their careers more often than their counterparts from Eastern Europe. According to Triandis, the Western European cultures, being mostly individualist cultures, also tend to be planning cultures (Stambulova, Alfermann, Stauer \& Côté, 2009; after Triandis, 2004).

Apart from the micro-social and macro-social dimensions of finishing a sports career, the role of different sports management systems should not be refuted.

"Among culturally specific features found in cross-national comparisons, it is worth noting that in China, Russia, and France retired athletes tend to relocate within sports (e.g., by starting a career as a coach), while this occurs less frequently in Germany and Sweden, where sports systems do not provide many paid jobs. In China, there is 'a close relationship and cooperation between university and sports system' (Huang et al., 2001, p. 10), which can help elite athletes with sports-related education and can provide them with jobs in sports after they finish their athletic careers. The same tendency can be observed in Russia, whereas in Germany, France, and Sweden, athletes themselves take full responsibility for their education and employment" (Stambulova, Alfermann, Stauer \& Côté, 2009, p. 12).

Literature abounds in empirical studies regarding former professional tennis players (Allison \& Mayer, 1988), hockey players (Curtis \& Ennis, 1988), baseball players (Lerch, 1981), amateur track and field athletes, rowers, and volleyball players (Koukouris, 1994). These reports, however, fail to account for cultural context or other macro-social factors, and their results cannot be relevant to the situation of former athletes from Poland and other Eastern European countries experiencing political and social transformations of the late 1980s and the early 1990s.

"Popular political and economic discourses have presented the events of 1989 in Eastern Europe as a move from state socialism to capitalism and from a planned to a market economy. A similar discourse predetermines two key dimensions in analyzing change - the direction and starting point. It implies that change is a linear move between two destinations (e.g., from communism to capitalism) with 1989 as its starting point, and that it represents a total break with history" (Girginov, 2008, p. 23).

The collapse of communism in 1989 and the reality of political and socio-economic transformations in the region created a situation which requires researchers to consider the possible impact of such macrochanges on their research subjects.

Until 1989, Polish society had functioned in conditions of a socialist system featuring such elements as an authoritarian state, a centrally planned economy, and rationing. These aspects deeply affected all spheres of life in Poland, including sports. The communist authorities regarded sports as a useful propaganda tool for strengthening their ideology, developing socialist attitudes, regulating social mobility, emphasizing differences between privileged and underprivileged social classes, and propagating such ideological values as collectivism and egalitarianism (Bomirska \& Woźniak, 1994).

Participation in sports in communist Poland was a chance for social advancement or even for entering the most privileged social elites (Bomirska \& Woźniak, 1994). An athlete's position in the social hierarchy was determined by non-sports subjective factors (personality traits, interests, attitudes, motivation, and values), objective factors (sports facilities, economic situation of the state), socio-demographic factors (age, 
sex, education, and place of residence), and sports aspects (sports type, function, and institutional framework). The social advancement of athletes also depended on social contacts, foreign contacts, cooperation, and conflict with other athletes (Bomirska \& Woźniak, 1994).

The changes observed in Polish sports after 1989 were mostly due to economic transformations of the country. The earlier system of the central financing of sports from the state budget became limited, or in some cases, even abolished. The world of sports was subjected to commercialism and market competition. Similar developments were observed in post-communist Czech Republic, where

"changes after 1989 have also meant a shift from a social approach in sports to a more 'market-oriented' one, based on the principles of capitalism. One consequence of this shift is that the social exclusivity and support of former top-level athletes prior to 1989 has largely disappeared with most former top-level athletes losing any public social support leading to a wide range of social problems" (Kadlcik \& Flemr, 2008).

On the other hand, the sports community in communist Poland was not as self-contained as other professional circles (which were marked by nepotism and control of material resources). Thus, the pace of the post-1989 transformation of the Polish sports community was much quicker than in other social and professional communities (Bomirska \& Woźniak, 1994).

There have been very few empirical studies regarding the situation of former athletes in communist and post-communist countries in Eastern Europe. With the exception of Svoboda and Vanek (1982), there is generally a shortage of comprehensive studies focusing on the region (Kadlcik \& Flemr, 2008). One of the most valuable works concerning the issue in Poland was a study by Pawlak (1983), who examined the lives of former athletes in the context of their social and economic situation ${ }^{1}$. In her study, Pawlak concentrated on Polish Olympic athletes in communist times. The study results pointed to the significance of the educational threshold in their post-sports life. Three patterns of crossing the educational threshold were distinguished. The first was the parallel development of a sports career and education followed by professional work. This pattern allowed the rapid adaptation of an athlete to his/her post-sports life, although this required tremendous diligence, good organization, and numerous sacrifices. Athletes who followed this model experienced little difficulty in their professional life after finishing their sports careers. Their entry into professional life was simply delayed when compared with their non-training counterparts.

The second pattern involved an educational gap period, i.e., a break period from scholastic education that allowed a person to focus on sports development and the achievement of sports successes. An athlete would then continue education at the peak of his sports career. Athletes following this model were motivated by peer pressure and increasing social aspirations. This group of athletes experienced considerable hardships in their post-sports professional life as, in many cases, they were forced to combine their occupational life with further education.

In the third pattern, sports success became a substitute for all life achievements, which resulted in the discontinuation of education for the duration of the athletes' sports career. For this group of Olympic athletes, the educational threshold was below their aspirations at the time of the completion of their sports careers. Nonetheless, most of them managed to complete their education. The analysis of data on athletes' education during their preparation and participation in the Olympics, as well as during the course of the survey, reveals a dynamic increase in the education level of the athletes under study. After the termination of their sports career, $43 \%$ of the Olympic athletes upgraded their education. Ultimately, $41.5 \%$ received a higher education (18.4\% during the Olympic Games); 35\% - a secondary education (44\% during the OG);

\footnotetext{
${ }^{1}$ The research material was collected between 1977 and 1982. A. Pawlak used an interview survey by mail. The sample consisted of 240 respondents, which was proportional to the total population of Polish athletes competing at the Olympic Games between 1948 and 1972. Out of 206 athletes who agreed to take part in the study, 36 were randomly selected. In-depth interviews were used. The respondents' declarations about their legal and economic situation were compared with official and personal documentation, press articles, books, and interviews given by the respondents to the media.
} 
$15.4 \%$ - a vocational education (17.3\% during the OG); and $5.55 \%$ - a primary education $(15.4 \%$ during the OG). In the ranking list of groups of athletes with an education completed during the OG, fencers were ranked second with a mean education index of $x=3.4$ pts. (index values: 4 pts. - higher education, 3 pts. secondary education, 2 pts. - vocational education, 1 pts. - primary education). In comparison with data from the time of the survey, i.e., after the athletes completed their sports careers, the former fencers' education index increased by 0.2 pts. (Pawlak, 1983).

At present, a new pattern of ex-sports life can be observed. Until recently, the link between a sports career and life after it was, first of all, an athlete's education. Today the value of education is being replaced by the high material status gained by athletes during their professional sports career. Pawlak (1983) called this pattern a "shortcut" and predicted it would be based on two components: athlete's sports success and financial stability. Education would cease to become a key factor influencing athletes' post-sports lives. Also, the declining popularity of sciences and humanities majors, as well as an increased interest in physical education studies, has been observed among students. According to Pawlak (1995), we now experience vocational and professional sports activities. At the same time, the "Olympic athlete" becomes a "sports professional for life."

The above trends are components of the process of sports professionalization, closely linked to social and economic transformations in Poland. The period of post-communist transformation and free market development made following of the mentioned "shortcut" path possible. It appears that the situation of Polish athletes at the end of their sports career today is quite different to that of their counterparts prior to 1989. In the Polish People's Republic, those who achieved public success became sports heroes. At present, sports results alone are enough for athletes to reach sports stardom. This change has been significant. While the former situation was connected with social prestige, the latter is associated with financial benefits. It can be assumed that the problem of employment of ex-athletes in the present-day socio-economic situation in Poland will grow. An athlete today can, on the one hand, reap enormous financial gains and become a sports celebrity. Certainly, he or she must be absolutely professional and look good in the media. On the other hand, for individuals who devoted many years to sports training in their youth but failed to achieve the highest success, the free market is merciless: those who lack competence and experience become excluded. From this perspective, athletes can be viewed as a social group facing the threats of unemployment and marginalization.

The process of unlearning of athletes takes a different turn, depending on the causes of one's completion of a sports career as well as on social and demographic factors (age, gender, social class, and education). The sociology of physical culture makes a sharp distinction between finishing a professional sports career and an amateur sports career. Amateur athletes often withdraw from sports because their objectives outside sports become more important to them. The reasons for this withdrawal include the declining value of sports in contrast to other forms of activity (study, work), a lowered rank of sports success as a lifelong objective, the lack of support for sports from the athlete's social circle, and the decreasing significance of the athlete's role in the process of self-identification. A truly negative consequence of a sports career termination can be observed in former professional athletes. It is connected with uncertainty in the job market, professional fluctuation of athletes, and relegation to a lower league. Athletes experiencing maladjustments in the post-sports reality often have a low education level and experience difficulties with contacting other professional groups. They often suffer from emotional problems and experience a sense of being pulled down from the peak of their career as well as lack of security (Wanat, 1995).

The present study tackles the issue of finishing a sports career in a sociological perspective, while also taking into consideration relevant psychological factors. It attempts to examine the issue of ex-athletes achieving stability in social life through the examination of Polish former amateur fencers. The following areas of life of these fencers were scrutinized: a) professional life, b) financial situation, c) family life, d) health. To varying degrees, a sports career excludes an athlete from important dimensions of social, economic, and cultural life. The consequences of this exclusion can be seen after the athlete's completion of the sports career. To understand these consequences better, a question should be posed whether and how 
one's participation in sports affects achievement of social stability in post-sports life. Also important are the consequences of practicing professional sports for athletes' future lives. The selected research sample was by no means representative of the whole population of Polish fencers. However, due to difficult access to many respondents, the collected empirical material is unique.

\section{Methods}

The study sample consisted of 51 Polish former fencers (35 men and 16 women). The purposive sampling (Babbie, 2004) technique was used in the selection of the sample. The following criteria of subjects were taken into account: 1. Former fencers; 2. Completed their sports career in 2004 at the latest (minimum 5 years of retirement from sports); 3 . Sports level - any fencing class; 4 . Competitive experience - minimum 5 years. The largest group of respondents was composed by former fencers born between 1959 and 1969. Their mean age was 45 years and competitive experience 12 years. The respondents were top Polish and worldclass fencers. Of the sample, $82.4 \%$ were fencers of international championship class, Polish championship class, and first class. The majority of them took part in international competitions such as the Olympic Games, World Championships, and European Championships. They were elite athletes in Poland, as indicated by their official classification by the Polish Fencing Association.

The remaining fencers finished their sports careers in 2004 at the latest. Initially, we had intended a comparative analysis of the situation of former athletes who finished their sports careers in communist Poland with those whose careers developed and finished after 1989. Such a comparison would have revealed the effects of the socio-economic situation on the athletes' lives. Unfortunately, the small sample size did not allow drawing a comparative profile of those fencers who finished their sports careers in the Polish People's Republic (before 1989) and after the political transformations in Poland, i.e., in conditions of free market economy. The majority of them - 32 subjects - completed their sports careers between 1969 and 1989. Despite this shortcoming, we were able to grasp and describe certain tendencies.

The study used a survey questionnaire technique (Babbie, 2005). The fencers were to answer a number of close-ended and open-ended questions to determine:

1. The reasons for completing their fencing career,

2. How the completion of their sports career affected their professional life,

3. How the completion of their career affected their family life,

4. Their material situation,

5. Their state of health,

6. General influence of their sports career on their life.

The former fencers were contacted by courtesy of fencing coaches, referees and sports club activists, some of whom fulfilled the purposive sampling criteria and agreed to take part in the survey. The youngest respondents were contacted through active fencers. Many respondents were reached thanks to the Polish Association of Veteran Fencers. The snowball sampling technique was also used (Babbie, 2004), whereby respondents provided contact data of their colleagues who also used to practice fencing. The data were collected from January to May 2009 and processed statistically with the aid of the SPSS software package.

\section{Findings}

Termination of a sports career always has some reasons. In the study sample of former fencers, the respondents' decisions to finish their sports careers were a result of a number of causes: sports injuries $(19.6 \%)$ and difficulties in harmonizing sports training both with professional work (19.6\%) and with personal life (15.7\%). It should be noted that the main reasons for abandoning a sports career derive from athletes' difficulties in fulfilling their sports and non-sports roles at the same time. In the event of conflict between two roles, the fencers most often chose the roles related to their professional and family life. 
Table 1. Causes of sports career termination by respondents

\begin{tabular}{lc}
\hline Reasons sports career termination & $\mathbf{\%}$ \\
\hline Injury & 19.6 \\
Difficulties reconciling training with professional life & 19.6 \\
Difficulties reconciling training with private life & 15.6 \\
Conflict with fencing club or national fencing & \\
federation representative & 11.7 \\
Relocation & 9.8 \\
Decline in sports achievements & 9.8 \\
Conflict with a coach & 7.8 \\
Difficulties reconciling training with education/study & 7.8 \\
Burnout & 5.8 \\
Aging in sports area & 5.8 \\
\hline * values do not add up to 100\% & \\
Source: own study. &
\end{tabular}

It is impossible to examine the lives of exathletes without referring to their sports careers. After the completion of a sports career, the life of an ex-athlete (especially an amateur one) does not make a U-turn. This is because the social role of athlete is not his or her only role. The problem may occur, however, if one's participation in sports has rendered performance of other social roles (professional, family) impossible. The resulting deficiencies in education or relationships with family members can be significant barriers for a former athlete to attain stability in social life.

\section{Professional life}

In the case of ex-fencers, the sphere of professional life is inseparably linked with the education level. Most subjects had a higher education (74.5\%). Considering the fencers' education paths, first jobs, and the time of completion of their sports careers, the following five strategies of entering the labor market can be distinguished among the respondents:

\section{Finishing one's education and taking a job right after finishing a sports career}

This strategy was adopted by $35 \%$ of the respondents. This group was divided into two subgroups based on the fencers' age and competitive experience. The first subgroup consisted of fencers who concentrated on education (younger, with shorter fencing experience upon completion of their sports career). For them, the role of fencer was simply a period in their role of school student. In this subgroup, 10 respondents had a higher education. They had given up fencing when they started their college education. They were full-time students and did not work during their college studies. Only three respondents from this subgroup admitted, however, that they finished their sports career because they were forced to choose university education over sports. It can be thus assumed that concluding their sports career after education and pursuing a professional career was for the majority of them a natural order of things (as with for most non-training subjects).

The other subgroup was composed of fencers who focused on their sports career (older, with longer fencing experience on completion of their sports career). For them, completing education after they finished their sports career was a form of making up for the lack of skills and competences in their role of fencers. For these ex-fencers, sports was a way of earning a living; the termination of their sports career necessitated seeking a new job.

\section{Finishing one's education during a sports career, giving up the sports career, and starting a job}

This strategy was chosen by $20 \%$ of the respondents. In their case, finishing one's education became an impulse to retire from sports and earn a living.

\section{Finishing one's education during one's sports career, and working a job alongside a sports career}

This strategy was followed by $27 \%$ of the respondents. It consisted of the parallel fulfillment of the roles of athlete and student. The role of student, however, was merely a period in one's sports career, later replaced with the role of a professional. 


\section{Starting a job during one's sports career, finishing education upon completion of one's sports career}

This strategy was pursued by $14 \%$ of the respondents. Beginning or continuing education upon completion of a sports career was a form of raising one's skills and increasing the chances of finding a good job.

\section{Finishing one's education and staring a job before commencing a sports career}

These respondents started their fencing career much later than the rest of the sample.

For more than one half of the respondents (55\%), their occupational activities began after completing their sports careers. Of the respondents, $45 \%$ of the ex-fencers were working jobs and pursuing sports careers at the same time, and most of these $(77.7 \%)$ continued the jobs they began during their sports career. The others were made redundant after they had retired from sports and had to seek a new job. These were mostly athletes who during their active sports career had been working at so-called "fictitious jobs" in the Polish People's Republic before 1989. In communist Poland, professional athletes did not formally exist. Instead, athletes were formally employed in different branches of industry or the military and earned their wages for sports training and competing. This meant that, in practice, athletes received certificates of employment confirming their professions and occupations they, in fact, had never followed. According to Lipoński (2002), this covert professionalism was a case of hypocrisy of state amateurism typical for the Polish People's Republic, which began to decline after 1989 together with the mentioned "fake jobs".

The ways in which the fencers reconciled professional work with sports activities (including their trips to sports events and training camps) are worth mentioning. For those with the fictitious jobs, this reconciliation posed no problems at all:

"I was delegated to the sports club and never had any problems with getting a leave of absence".

In other situations the problem of absences at work was solved in formal, semi-formal, or informal ways. The respondents took vacations or unpaid leaves. Semi-formally, the club "secured" the fencers their doctor's leaves, and informally, they made arrangements between each other:

"We used to agree on peer substitutions".

Coaches and instructors sometimes resorted to cancelling training sessions:

"I simply gave my group of athletes a day off".

What was the situation of the fencers after they finished their sports careers? These respondents (who were working so-called "fictitious jobs") admitted they used the help of their family members, coaches, or activists from their sports clubs in finding a new job. The significance of this support was also confirmed in a study of Czech athletes (Kadlcik \& Flemr, 2008) who despite finishing their careers in the democratic Czech Republic, found their social contacts to be really helpful on the job market. The impact of the support of family and friends is characteristic in post-communist societies in which "state-organized" job-seeking strategies and collectivist behaviors from the communist times are still observed. As noted by Koczanowicz:

"One of the paradoxes of social life under the communist government was that people did
not trust any service that the government provided. People learned how to behave in a no
man's land between state-organized social life and the demands of their personal situations.
So everybody had to have a lot of individual initiative to survive but the problem was that it
was an initiative restricted of the conditions of existing social institutions. (...) it was also
clear that the communist ideology was right in this respect that an individual could not
survive without the help of others. Contrary to the official ideology, however, those others
come from the closest social milieu: friends and family. Collectivism then appeared at the
pre-modern level of 'natural ties' of kinship and locality crossing the lines of the political
divisions" (Koczanowicz, 2003, pp. 21-22). 
What is important is that none of respondents confirmed an unsuccessful combination of their sports career with attainment of professional skills resulting in difficulties on the job market. None of the respondents is currently unemployed, and only one is retired, while $4 \%$ remain professionally active despite being at the age of retirement. Out of all the respondents, $58.7 \%$ are currently practicing their learned profession, working as sports coaches, physical education teachers, and university lecturers (mainly at University Schools of Physical Education). This is similar to the situation in China, Russia and France, where athletes, upon on completing their sports careers, simply switch their occupational roles (Stambulova, Alfermann, Stauer \& Côté, 2009 after Alfermann, Stambulova \& Zemaityte, 2004; Schmidt \& Hackfort, 2001; Huang, 2001; Hackfort \& Huang, 2005).

Another category consists of individuals who decided not to link their professional future with sports and have worked in a variety of non-sports professions, including a ceramist, economist, electrical engineer, IT specialist, bookbinder, tailor, accountant, construction engineer, civil engineer, metallurgist, construction worker, mechanic, cardiologist, physical therapist, teacher, political scientist, lawyer, dress designer, construction technician, and economic technician.

Table 2. Current job satisfaction (\%)

\begin{tabular}{lc}
\hline Are you currently satisfied with your job? & \% \\
\hline Definitely yes & 36.7 \\
Rather yes & 51.0 \\
Neither yes nor no & 6.1 \\
Rather no & 4.1 \\
Definitely no & 2.0 \\
Total & 100 \\
\hline
\end{tabular}

Source: own study.
The majority of respondents $(64.8 \%)$ are employed fulltime; $9.3 \%$ have worked more than one job, almost $20 \%$ have flexible work hours. Two subjects have worked part-time and one has done odd jobs. Overall, the exfencers have enjoyed professional, and, presumably, financial, stability. Regardless of their occupation, $88 \%$ of respondents were satisfied with their occupational life.

\section{Financial situation}

Almost three-quarters of former fencers regarded their present-day financial situation as better than it was during their sports career, when, regardless of their sports level, financial and material benefits from sports training and achievement of sports successes were neither consistent nor significant. During their sports careers, fencers in communist Poland bore low costs of practicing fencing. They were supplied with the fencing weapons, clothing, and masks and incurred no expenses related to their meals and trips to training camps and fencing competitions. Moreover, they also received sports stipends to cover daily living expenses $(43.1 \%)$ and clothes $(21.5 \%)$. Completion of a sports career did not involve downward mobility, because they already worked outside of sports to support their families. The former fencers' self-assessment of their present-day financial situation was very positive indeed. Only $2 \%$ of them reported their financial status as poor, as compared with $34 \%$ of the Polish population (according to data from the Polish Center for Public Opinion Research (CBOS), CBOS Report BS/61/2009).

Table 3. Assessment of financial situation by former fencers and general Polish population (\%)

\begin{tabular}{lcc}
\hline \multicolumn{1}{c}{ Financial situation } & $\begin{array}{c}\text { Former } \\
\text { fencers }\end{array}$ & $\begin{array}{c}\text { General } \\
\text { Polish } \\
\text { population }\end{array}$ \\
\hline I live very poorly - I do not have enough even for the basic needs & 0 & 6 \\
I live modestly - I have to dole out every day & 2 & 28 \\
I live on average - it is enough for every day but I have to save money & 43.1 & 52 \\
for serious shopping & 43.1 & 13 \\
I live well, it is enough for many things, even without special saving & 11.8 & 1 \\
I live very well, I can afford to a certain luxury & 100 & 100 \\
Total & & \\
\hline
\end{tabular}

Source: own study.

The former fencers owed their financial status to their jobs, education level, and a stroke of luck. Some stated that their fencing career, experience, and skills influenced their material status. 
Table 4. Determinants of financial stability in ex-fencers

\begin{tabular}{ll}
\hline You owe your present material status to: & \%* \\
\hline Professional work & 64.8 \\
Education & 64.8 \\
Luck & 25.9 \\
Fencing skills and experience & 24.0 \\
Relatives and friends & 18.5 \\
Myself / my personality & 12.9 \\
Sports achievements & 7.4 \\
Connections from the time of my sports career & 1.8 \\
\hline * values do not add up to 100\% & \\
Source: own study. &
\end{tabular}

\section{Family life}

Most of the former fencers were married (78\%), $17 \%$ remarried, $11 \%$ live in a civil union, and $6 \%$ are single. The majority of respondents who had divorced were remarried or lived in a civil union. Only two remained divorced at the time of the study. The majority of former fencers had a stable family life after they concluded their sports career. Out of those who married during their sports career only three were subsequently divorced. All the divorcees stated that their sports career was not a cause of the break-up of their marriages.

The respondents were asked whether their participation in training camps or sports competitions was an issue in their family life. They stated it was not a problem, but at the same time admitted that often they pursued their sports careers at the expense of their family life, even though they felt they had the acceptance and support of their spouses. For example, a xx-year old woman said:

"My husband supported my fencing career. He was always helpful. I also had great support from my parents and in-laws".

Similarly, a xx-year old man stated:

"I was a guest in my own house, but fencing was my work and my wife had to accept it".

"I tried very hard and had a truly understanding wife-athlete".

Another respondent admitted less optimistically:

"My wife just grinned and bore it".

The former fencers also indicated that they used different strategies for coping with separation while at training camps or fencing tournaments, which permitted communication only by letters or phone. Some of them admitted experiencing difficulties at reconciling their fencing careers and family life. At some point, they were forced to choose the latter over the former:

"I somewhat managed to reconcile my family life with my sports life, but not for long. I then chose to commit to my personal life and professional work".

The vast majority of respondents (88.2\%) have children: $47.7 \%$ with two children and $36.4 \%$ with one child. $73.3 \%$ of them had children after the end of their sports career. These respondents admitted experiencing more frequent difficulties with reconciling their sports career with family life. They coped with these hardships with the help and support of their family members:

"My husband, mother and mother-in-law helped me a lot".

They often emphasized that their children also participated in their sports career:

"I took my daughter to training camps with me".

"I was supported by my mother and in-laws. The Polish Fencing Association was also very helpful. I was allowed to take my kid to training camps. In the first years my mother went with me and she took care of my child. When my child was three I took him alone. He never interfered with my training".

Some fencers were unable to reconcile the two roles:

"I had to give up fencing to look after my kids".

The majority of the respondents stated that their children had positive attitudes toward their professional sports careers: 
"They were very interested in all my sports competitions; they also often attended them".

"They were impressed".

"My kid was very happy travelling with me to my training camps".

Some admitted, however, that the children didn't always accept the absence of their parents from home:

"They were little and they missed me".

Some fencers said they did not know their children's attitude toward their sports career.

Table 5. Family life vs. sports career of former fencers.

\begin{tabular}{|c|c|c|}
\hline & $\begin{array}{l}\text { When did you } \\
\text { get married? } \\
\text { (first time) }\end{array}$ & $\begin{array}{c}\text { When } \\
\text { was/were your } \\
\text { child/children } \\
\text { born? }\end{array}$ \\
\hline & $\mathbf{N}$ & $\mathbf{N}$ \\
\hline Before I began my fencing career & 1 & 1 \\
\hline During my fencing career & 15 & 9 \\
\hline After finishing my fencing career & 30 & 33 \\
\hline During my fencing career and after its completion & - & 2 \\
\hline Never & 5 & 6 \\
\hline Total & 51 & 51 \\
\hline
\end{tabular}

Source: own study.

Physical activity patterns in the fencers' families often were passed from generation to generation. Undoubtedly, their family life served as a sphere of socialization in which young family members were introduced to physical culture and sports. For example, more than three-quarters of the respondents reported they continue to pursue various forms of physical recreation, and that their family members are physically active and engage in sports more often than in recreation.

This transfer of physical activity patterns is stronger with each generation. Only five respondents had parents that had past competitive experience and twelve fencers had siblings who had been professional athletes. However, nearly half of the fencers' children practiced sports. The respondents constituted the generation that initiated fencing traditions in their family. Those whose children did not practice or never practiced fencing were asked if they ever encourage their children to engage in the sports, and those with no children were asked if they ever encouraged their friends' children to participate in fencing.

Table 6. Attitudes towards practicing fencing by former fencers' friends' children

\begin{tabular}{lc}
\hline $\begin{array}{l}\text { Would you like your children to practice fencing? } \\
\text { (respondents with children) }\end{array}$ & $\mathbf{N}$ \\
Would you encourage your friends' children to & \\
take up fencing? (respondents with no children) & \\
\hline Yes (they practice/practiced fencing) & 10 \\
Definitely yes & 6 \\
Rather yes & 13 \\
Neither yes nor no & 17 \\
Rather no & 5 \\
Definitely no & 0 \\
Total & 51 \\
\hline Sourc:
\end{tabular}

Source: own study.

Those respondents who stated that they would encourage the younger generations to take up fencing justified their position by referring to the educational value of sports: 
"I see only good points in fencing. It improves health, has a great educational quality, and develops psychical traits (self-reliance, purposefulness of one's activities, initiative, and selfcontrol). It improves one's general fitness and enhances life skills".

Some stressed the health dimension of fencing, however, in the context of its comparatively lower harmfulness than other sports:

"Sports are good for children. They can find in it an outlet for their energy. Fencing is not brutal and less injury prone than, for example, team games".

"Fencing has many health benefits. It does not exhaust the body and is interesting".

Others emphasized autotelic qualities of fencing, calling it "cultural", "elite", "spectacular", "beautiful", and "super". The main negative features of fencing were reportedly the high price of fencing equipment: "It is an expensive sports and sports clubs run out of money", plus the numerous sacrifices and health risks.

One of the ex-fencers enumerated all these aspects:

"It is a sports for enthusiasts. One must love it to persevere in fencing through hard training. Fencing is not an opportunity for quick profits. No one is going to buy tickets to a fencing event, as fencing is not a truly spectator sport. Fencing is for young people. At the age of 30 every fencer becomes a veteran, unlike a tennis player, runner or swimmer. I guess fencing also strains the knees too much".

One respondent described fencing as a "manly" sports, not suitable for women:

"There is too much aggressiveness in fencing. My daughter should be a more delicate person".

It appears that former fencers saw family as the most important sphere of their lives. They said that reaching stability in family life, starting a family, and ensuring happiness in the family were the most important elements in defining their life as successful (60.7\%). Occupational and sports successes (27.4\% and $7.8 \%$, respectively) were rated much lower in their hierarchy of values.

\section{Health}

More than one-third of former fencers sustained major injuries during their sports career. Of those, 10 fencers were forced to end their careers due to an injury. Knee injuries to cruciate and collateral ligaments, menisci, and articular cartilages were the most common. Injuries to the ankle (Achilles tendon, joint capsules), thigh, and shank also were common. One respondent suffered an elbow injury. The fencers also mentioned dangerous broken blade accidents:

"During a foil training bout my fencing partner pierced my hand with his foil tip. I was rushed to the emergency room and received an anti-tetanic injection. I was then admitted to a dermatology department ... It was a life-threatening situation, I was suffocating. I could not train for three month".

"I was injured with a broken epee blade during an exhibition bout in Krakow in 1966. Nothing serious, no consequences. Much worse are my strained knees and slipped disks (....) Piercing accidents do happen in fencing. I know of three such accidents: $x$ was pierced once with a foil, my friend's wife pierced him accidentally during training; $x x x$ was pierced with an epee, as he is left-handed the blade passed near his heart. Not to mention my own accident at the championships".

It turns out that with the passing of time, only long-term health consequences of practicing professional sports become visible. At present, the respondents suffered from some dysfunctions of the skeleton (31.3\%), muscles $(9.8 \%)$, and internal organs (mostly gastric disorders) $(5.8 \%)$. The fencers perceive these health problems as consequences of untreated injuries and physical degeneration during their sports career. Most fencers experienced lower back pain and described it as scoliosis. Nearly half of the 
sample declared no health problems or only minor troubles (headaches, toothaches); $96 \%$ reported that they were in a good frame of mind, including most of those who admitted that they had health problems. Only one person admitted feeling really bad. These results correspond to those obtained by Pawlak (1983), who observed that athletes tended to make a subjective evaluation of their health much better than objective health assessment results might suggest.

Table 7. General feeling

\begin{tabular}{lc}
\hline How do you feel, considering your age? & N \\
\hline Very well & 29 \\
Well & 20 \\
Bad & 1 \\
Very bad & 0 \\
It is hard to say & 1 \\
Total & 51 \\
\hline S
\end{tabular}

Source: own study.

Of all motor traits influenced by fencing practice, reaction time was mentioned most often by the respondents; $7.8 \%$ listed staying slim as a health benefit rather than an aesthetic quality. Good mental health was also underlined as a positive result of fencing practice: according to $9.8 \%$ of the respondents, they owed their good mood and life optimism to practicing fencing. In many cases the fencers compared themselves with their non-training counterparts. In each case, they assessed themselves higher and admitted to enjoying a good frame of mind thanks to sports practicing in the past:

"I have no health problems. In comparison to people at my age I feel younger, I'm in better shape, sense of humor and frame of mind. Fencing has had a preservation effect on me".

"I'm enjoying good health and frame of mind for a 50-year-old. People at my age experience all sorts of health problems. Not me".

The respondents revealed a pro-health attitude. For them, movement has a great health quality. About $63 \%$ declared they were practicing various forms of physical recreation to maintain good mental health. The means of maintaining good health included "movement", "physical effort", "intense activity", or particular forms of physical activity. Apart from its health benefits, physical exercise had also a hedonistic value for the respondents. Among activities undertaken to get rest or to relax physical activity was most frequently mentioned by the ex-fencers $(74.5 \%)$.

It appears that practicing professional sports in one's youth is conducive to participating in physical recreation at an older age. This may be a surprising conclusion regarding the injuries sustained by the respondents. The most popular form of recreation undertaken by the former fencers is cycling (47.7\%), which also happens to be the most popular recreation form among the general Polish population (CBOS Report BS/23/2003). The respondents have undertaken various forms of all-year and seasonal physical activity: jogging, swimming, fitness exercises, Alpine and cross-country skiing, ice skating, sailing, kayaking, and windsurfing.

It should be emphasized that one must have both the skills and the financial means to practice these sports. Only $11.7 \%$ of the respondents do not practice any forms of physical recreation. No correlation has been observed between taking up physical recreation by former fencers and past injuries or health problems. It is interesting that the respondents carefully choose forms of physical recreation with regard to injuries and health problems experienced during their sports careers. Fencing and fencing-related injuries have not precluded physical activity, but merely made the respondents select appropriate forms of physical recreation:

“My old knee injuries made me choose swimming as the only recreation form I can pursue”.

"In 2004 I underwent a knee arthroscopy. The surgeon removed fissured cartilage parts from my right knee, which had pressured my nerves. I had been unable to walk. Now there is a limit 
to the number of kilometers I can walk every day. Fortunately, when I ride my bike I feel no pain in my knee joint".

When the fencers retired from their fencing clubs, their health care ceased to be provided by the sports community. For $94.4 \%$ of respondents, the completion of their sports career meant they could not use services of their sports medical centers. However, it is important to remember that any fencing-related health problems have not eliminated former fencers from social life, despite being excluded from the sphere of professional sports.

\section{The significance of a sports career in later lives of former athletes}

The respondents declared that their sports career had a significant influence on their present life (74.5\%). For $9.8 \%$ this influence was imperceptible, while $15.7 \%$ of the fencers had no opinion on this issue. With the exception of one respondent, those who thought fencing affected their life judged this influence positive.

Although none of the respondents assessed the overall impact of their sports career on their life as negative, 22.2\% noted negative aspects in some areas of their life. First, they emphasized negative consequences for their health (these respondents constituted one-third of all those who had sustained serious injuries during their career). Secondly, they reported that focusing on a fencing career made them neglect their family life, professional work, and leisure pursuits.

The respondents reported diverse positive consequences of their sports career. Nearly half of the respondents pointed to the educational role of sports, and stated that by participating in sports they became prepared for their adult life and acquired useful skills for their professional careers, regardless of their occupation. The personality traits reportedly developed during their fencing careers included self-reliance, responsibility, persistence, methodical, self-confidence, and diligence. For $24 \%$ of the respondents, their fencing career prevented them from developing social relationships. Thanks to their participation in sports, however, they established lifelong friendships. They noted also the entertainment dimension of fencing. For them, practicing fencing was primarily a source of joy, satisfaction, and a realization of dreams. From a time perspective, the respondents retain positive memories from their fencing days. One-fifth noted long-term health benefits of fencing. For $17 \%$ of the respondents, fencing was a ticket to see the world: they think that if they had not been professional fencers, their foreign trips would not have been possible financially and formally, especially in communist Poland before 1989. Many stressed the development of the habit of an active lifetime, and for $9.3 \%$ fencing contributed to their choice of a lifetime profession:

"My fencing career became a pass to my coaching profession. The skills and techniques I learned as a fencer I used later in my professional work (...)".

The number of such declarations, however, was very low in comparison with the actual number of respondents who decided to pursue a sports-related professional career after finishing their fencing career.

\section{Discussion and conclusions}

The paper discusses the issue of social stability attainment by former fencers in the context of Polish post-communist society. It turned out that after completing their fencing careers, the respondents successfully achieved social stability in life. In the case of Polish former fencers, their retirement from sports should not be regarded as "social death". The results of the study confirm that retirement from sports does not have to be a negative development in an athlete's life (Coakley, 1983; Kadlcik \& Flemr, 2008). Just as in a study of Czech athletes (Kadlcik \& Flemr, 2008), respondents in this study experienced significant social, health, and economic changes in their lives after finishing their sports careers. The most frequent cause of retirement from sports both for the Polish fencers and the Czech athletes was a sports injury. Unlike the Polish fencers, the Czech respondents more often indicated sports-related reasons than non-sports related reasons for termination of their sports careers. It must be emphasized that the Czech pattern of retirement 
from sports is based on a transition from within sports to outside sports and on planning athletes' ending of careers before the actual retirement from sports. The survey of Polish fencers focused on the lives of former fencers after completion of their careers in a longer perspective. The study did not consider the period immediately before the end of fencers' careers nor the transition itself. It is therefore impossible to compare all tenets of the Czech model of retirement from sports with the result of the present research. The Czech researchers duly observe that the process of former athletes' adaptation to post-sports reality must account for country-specific sports management systems and socio-economic situations (Kadlcik \& Flemr, 2008). Thus, the present study attempted to place the issue of former athletes' adaptation in a wide social context. The political and social transformations in Poland primarily affected the occupational life of former fencers (e.g., none of the respondents training after 1989 worked "fictitious jobs" in free Poland). Still, job-seeking strategies characteristic of post-communist societies can be observed among former fencers in Poland (collectivist behaviors, reliance on family and friends' support in employment seeking). A number of respondents decided to remain in the sports community and only change their professional roles. They became coaches, sports instructors, or physical education teachers. In this regard, sports in Poland, or at least fencing, follow the patterns in China, Russia and France, where the sports communities create job opportunities for retired athletes (Stambulova, Alfermann, Stauer \& Côté, 2009 after Alfermann, Stambulova \& Zemaityte, 2004; Schmidt \& Hackfort, 2001; Huang, 2001; Hackfort \& Huang, 2005). It should be emphasized that key to the respondents' occupational stability was their education, and that the significance of overcoming the educational threshold for the functioning in extra-sports reality was clearly confirmed (Pawlak, 1983). Most of respondents had been forced to choose strategies and actions during their fencing career to ensure professional, financial, and family stability in the future. Those who encountered hardships in combining the role of athlete with the other social roles were most often forced to give up fencing.

In the case of the family and health spheres of the respondents' lives, the political transformations were rather insignificant. These spheres of life are not so much affected by macro-social as by micro-social changes. For the former fencers, however, family life was the most important sphere; an ex-fencer's home was a reflection of the model of a regular Polish family (a married couple with one or two children). The respondents did acknowledge a multidimensional impact of sports practicing on their current lives.

The present study does not constitute a comprehensive analysis of the issue of social stability of retired athletes. However, the obtained results can be regarded as a starting point for a much wider discussion on the functioning of the sports system and the situation of former athletes in Poland. Today's sports demand a narrow professional specialization from athletes. Amateurism has virtually disappeared from international sports competitions. It can be assumed that after finishing their careers, athletes can become more and more lost in the new reality. As long as sports are changing, the problems facing ex-athletes will change. Changes also affect our socio-economic reality. It is therefore important to continuously study the process of life stability attainment by former athletes.

\section{Acknowledgement}

The authors would like to thank Professor Leszek Koczanowicz from the University School of Physical Education in Wroclaw for his support and all valuable comments and suggestions.

\section{REFERENCES}

Allison, M., Mayer, C. (1988). Career problems and retirement among elite athletes: The female tennis professional. Sociology of Sports Journal, 5, 212-222.

Babbie, E. (2004). The Practice of Social Research. Warsaw: PWN

Babbie, E. (2009). The Basics of Social Research. Warsaw: PWN

Bomirska, L., Woźniak, R. (1994). Społeczne problemy sportsu w okresie transformacji ustrojowej w Polsce /Social Problems in Sports during Political System Transformation in Poland/. Roczniki naukowe AWF w Poznaniu, 47 - 59. 
CBOS Report BS/61/2009, Warsaw, April 2009 Retrieved April 5, 2010, from http://www.cbos.pl/SPISKOM.POL/ 2009/K_061_09.PDF

CBOS Report BS/23/2003, Warsaw, January 2003 Retrieved April 5, 2010, from http://www.cbos.pl/SPISKOM.POL/ 2003/K_023_03.PDF

Curtis, J., Ennis, R. (1988). Negative consequences of leaving competitive sports? Comparative findings for former elite-level hockey players. Sociology of Sports Journal, 5, 87-106.

Coakley, J. (1983). Leaving Competitive Sports: Retirement or Rebirth? Quest, 35, 1-11.

Drahota, J.A.T., Eitzen, D.S. (1998). The Role Exit of Professional Athletes. Sociology of Sports Journal, 15, $263-78$.

Ebaugh, H.F. (1988). Becoming an ex: The process of role elite. Chicago: University of Chicago Press.

Girginov, V. (2008). Understanding the Changing Nature of Sports Organisations in Transforming Societies. Sports Management Review, 11, 21-50.

Kadlcik, J., Flemr, L. (2008). Athletic career termination model in the Czech Republic. International Review for the Sociology of Sports, 43 , 251-269.

Koczanowicz, L. (2003). Civil society as an ethical challenge: Paradoxes of the Creation of the Public Sphere in Posttotalitarian Poland. Human affairs, 13, 20-33.

Koukouris, K. (1994). Constructed Case Studies: Athletes' Perspectives of Disengaging From Organized Competitive Sports. Sociology of Sports Journal, 11, 114-139.

Lerch, S.H. (1981). The adjustment to retirement of professional baseball players. In S.L. Greendorfer \& A. Yiannakis (Eds.), Sociology of sports: diverse perspectives: 1st Annual NASS Conference proceedings (pp. 138-148). West Point, N.Y.: Leisure Press.

Lerch, S.H. (1984). Athletic retirement as social death: An overview. In N. Theberge \& P. Donnelly (Eds.), Sports and sociological imagination (pp. 259-272). Fort Worth: Texas Christian University Press.

Lipoński, W. (2002). Sports. Poznań, 2002 Retrieved November 3, 2012, from http://www.wbc.poznan.pl/ dlibra/publication?id=40467\&tab=3

McPherson B.D. (1984). Sports participation across the life cycle: A review of literature and suggestions for future research. Sociology of Sports Journal, 1, 213-230.

Pawlak, A. (1995). Sports career/Kariera sportowa/. In Z. Krawczyk (Ed.), Sociology of physical education/Socjologia kultury fizycznej/ (pp. 265 - 266). Warsaw: University of Physical Education.

Pawlak, A. (1983). Status of Polish Olympians after end of sports career/ Status polskich olimpijczyków po zakończeniu kariery sportowej/. Warsaw: University of Physical Education.

Rosenberg, E. (1981). Gerontological theory and athletic retirement. In S.L. Greendorfer \& A. Yiannakis (Eds.), Sociology of sports: Diverse perspectives (pp. 118-126). West Point, NY: Leisure Press.

Rosenberg, E. (1984). Athletic retirement as social death: Concepts and perspectives. In N. Theberge \& P. Doneelly (Eds.), Sports and sociological imagination (pp. 245-258). Fort Worth: Texas Christian University Press.

Stambulova, N., Alfermann, D., Stauer, T., Côté, J. (2009). ISSP Position stand: career development and transitions of athletes. International Journal of Sports and Exercise Psychology, 7, 395-412.

Wanat, S. (1995). Physical education and personality /Kultura fizyczna i osobowośćl. In Z. Krawczyk (Ed.), Sociology of physical education/ Socjologia kultury fizycznej/ (pp. 87 - 88). Warsaw: University of Physical Education.

\section{AUTHOR'S ADDRESS:}

Agata Kucharska

Akademnia Wychowania Fizycznego we Wrocławiu

ul. Witelona 25, pok. 206

51-617 Wrocław, Polska

Email: agakucharska@op.pl 